\title{
OPTIMALISASI PERAN GURU BIMBINGAN DAN KONSELING DALAM PEMBENTUKAN KARAKTER SISWA
}

\author{
Ayu Santika Suroso \\ Institut Agama Islam Negeri Samarinda \\ E-mail : ayusantika54@gmai.com \\ Mohammad Salehudin \\ Institut Agama Islam Negeri Samarinda \\ E-mail : salehudin@iain-samarinda.ac.id
}

\begin{tabular}{|c|c|c|}
\hline Received & Revised & Accepted \\
\hline 10 Januari 2021 & 10 Februari 2021 & 28 Maret 2021 \\
\hline
\end{tabular}

\section{OPTIMALIZATION OF THE ROLE OF TEACHER CONSELLING AND GUIDANCE TO SHAPE STUDENT'S CHARACTER}

\begin{abstract}
Character education is an educational system that aims to instill certain character values in students in which there is a component of knowledge, awareness or willingness, and actions to carry out these values. The purpose of this research is to find out how important the role of counseling teachers is in shaping the character of students and how to deal with them. This study uses a qualitative approach with a descriptive type that aims to describe the role of the teacher as a role model in developing student character. One way to build character in students is to use the group guidance method. Group Guidance is one of the effective counseling techniques for character building students.

Keywords: the role of teachers, exemplary teachers, and students with character.

Abstrak

Pendidikan karakter ialah suatu sistem pendidikan yang bertujuan untuk menanamkan nilai-nilai karakter tertentu kepada peserta didik yang di dalamnya terdapat komponen pengetahuan, kesadaran atau kemauan, serta tindakan untuk melakukan nilai-nilai tersebut. Tujuan dari penelitian ini ialah untuk dapat mengetahui bagaimana pentinya peran Guru BK dalam membentuk krakter peserta didik serta bagaimana upaya untuk menanganinya. Penelitian ini menggunakan pendekatan kualitatif dengan jenis deskriptif yang bertujuan mendeskripsikan peran guru sebagai teladan dalam pengembangan karakter siswa. Salah satu cara untuk pembentukan karakter pada siswa ialah dengan menggunakan motode bimbingan kelompok, Bimbingan Kelompok merupakan salah satu teknik bimbingan konseling yang efektik untuk pembentukan karakter siswa.
\end{abstract}

Kata Kunci: peran guru, keteladanan guru, dan peserta didik yang berkarakter. 


\section{Pendahuluan}

Dalam UU Nomor 20 tahun 2003 pasal 4 ayat 4 tentang Sistem Pendidikan Nasional (SISDIKNAS) pendidikan diselenggarakan dengan memberi keteladanan, membangun kemauan, dan mengembangkan kreativitas peserta didik dalam proses pembelajaran. ${ }^{1}$ Belajar merupakan suatu usaha sadar manusia dalam mendidik dalam upaya meningkatkan kemampuan kemudian diiringi oleh perubahan dan peningkatan kualitas dan kuantitas pengetahuan manusia itu sendiri. ${ }^{2}$ Belajar adalah suatu aktivitas yang terjadi di dalam lingkungan belajar. Belajar diperoleh melalui lembaga pendidikan formal dan non formal. Salah satu pendidikan formal yang umum di Indonesia yaitu sekolah dimana di dalamnya terjadi kegiatan belajar dan mengajar yang melibatkan interaksi antara guru dan siswa. Tujuan belajar siswa sendiri adalah untuk mencapai atau memperoleh pengetahuan yang tercantum melalui hasil belajar yang optimal sesuai dengan kecerdasan intelektual yang dimilikinya. ${ }^{3}$ Tentunya dalam proses pembelajaran itu dilakukan di sekolah yang mana sekolah merupakan tempat kedua bagi anak untuk memperoleh pendidikan setelah lingkungan keluarga. Dengan sekolah, anak mampu memperoleh hak mereka untuk belajar serta mendapatkan pengajaran. Sekolah seperti sebuah rumah yang disanalah terbentuk keluarga kedua, yakni guru yang berperan sebagai orangtua kedua, dan segala pernak-pernik sekolah yang berada pada posisi kedua bagi anak. $^{4}$

Asal mula sekolah adalah sebuah anggapan masyarakat bahwa mereka tidak dapat mendidik anak mereka dengan sempurna, karena itulah adanya pendidikan akan mengantarkan anak untuk lebih baik lagi. Sebab, pendidikan adalah usaha sadar dan terencana yang dilakukan untuk membantu peserta didik secara sadar dapat menentukan masa depannya serta mampu mempersiapkan dirinya mengisi peran tertentu dengan baik pada masa depan dalam mengembangkan potensi diri agar berguna bagi kehidupannya. ${ }^{5}$

Secara umum pendidikan ialah salah satu faktor yang sangat penting di dalam kehidupan, hal ini disebabkan karena pada dasarnya manusia memiliki kekurangan dan keterbatasanya, maka untuk melengkapi keterbatasan tersebut manusia berproses dalam pendidikan. ${ }^{6}$ Salah satu layanan pendidikan sangat diperlukan

\footnotetext{
${ }^{1}$ Alam Nur, "Peran Guru Bk Dalam Mengatasi Penyalahgunaan Media Sosial Pada Siswa Di Kecamatan Walenrang Utara Dan Lamasi," Jurnal Panrita 1, no. 1 (2020): 31-40, https://doi.org/10.35906/panrita.vii1.130.

2 Tuti Hendriyani, "Optimalisasi Peran Guru Bimbingan Dan Konseling Dalam Mereduksi Nomphobia," Prosiding Seminar Nasional E Call Paper Psikologi Pendidikan 2019, 2019, 123-26.

${ }^{3}$ Menengah Pertama, Negeri Depok, and Rina Palunga, "Peran Guru Dalam Pengembangan Karakter Peserta Didik Di Sekolah Menengah Pertama Negeri 2 Depok Sleman," Jurnal Pendidikan Karakter 7, no. 1 (2017): 109-23, https://doi.org/10.21831/jpk.v7i1.20858.

${ }^{4}$ Anita Dewi Astuti, "Optimalisasi Peran Guru Bimbingan Dan Konseling Dalam Menguatkan NilaiNilai Moral Remaja Yang Berkarakter," Prosiding Nasional, 2017, 27-36.

${ }^{5}$ Hardi Prasetiawan, "Peran Bimbingan Dan Konseling Dalam Pendidikan Ramah Anak Terhadap Pembentukan Karakter Sejak Usia Dini," Jurnal CARE (Children Advisory Research and Education) o4 (2016): 42-49.

${ }^{6}$ Misra Wati, "Peran Guru BK Dalam Membentuk Karakter Siswa Melalui Layanan BK Kelompok," PEMBELAJAR: Jurnal Ilmu Pendidikan, Keguruan, Dan Pembelajaran 1, no. 2 (2017): 65, https://doi.org/10.26858/pembelajar.vii2.3482.
} 
disekolah adalah adanya bimbingan dan konseling. bimbingan dan konseling merupakan serangkaian program layanan yang diberikan kepada peserta didik supaya mereka mampu berkembang lebih baik. Pelaksanaan bimbingan dan konseling merupakan proses bantuan atau pertolongan yang diberikan oleh pembimbing (konselor) kepada individu atau kepada konseling. Dengan adanya Guru Bk di sekolah akan membantu mengembangkan karakteristik para siswa/peserta didik untuk menjadi lebih baik lagi kedepannya.

Bimbingan dan konseling bertujuan untuk membantu individu dalam mengembangkan diri secara optimal sesuai dengan tahap mengembangkan diri secara optimal sesuai dengan tahap perkembangan dan predisposisi yang dimilikinya (seperti kemampuan dasar dan bakat-bakatnya), berbagai latar belakang yang ada (seperti latar belakang keluarga, pendidikan dan status sosial ekonomi) serta sesuai dengan tuntuntan positif lingkungan. ${ }^{7}$ Secara teoretik, BK memiliki peran strategis dalam penguatan pendidikan karakter di sekolah. Peran tersebut dapat diwujudkan melalui makna hakikat layanan dan realisasi program dan layanan BK. ${ }^{8}$ Hakikat layanan BK adalah suatu proses bantuan yang diberikan kepada individu siswa secara sistematis dan berkelanjutan oleh seorang ahli yang telah mendapatkan pelatihan khusus, agar individu yang dibantu dapat memahami diri dan lingkungannya, mengarahkan diri, menyesuaikan diri dan mengembangkan potensi yang dimilikinya secara optimal, sesuai dengan nilai-nilai yang dianut, untuk mewujudkan kesejahteraan diri dan masyarakat. ${ }^{9}$ Terkadang Kondisi orang tua yang terlalu sibuk menyebabkan siswa kurang mendapatkan perhatian, sehingga sekolah menjadi tumpuan utama dalam penanaman karakter bagi siswa. Siswa cenderung masih suka bermain dan bersenang-senang dengan teman-temanya. Pada dasarnya pendidikan di perlukan untuk meningkatkan harkat, martabat dan kesejahteraan manusia, salah satunya penbentukan karakter peserta didik yang bisa di dapatkan dari pendidikan karakter. ${ }^{10}$

Pendidikan karakter ${ }^{11}$ ialah suatu sistem pendidikan yang bertujuan untuk menanamkan nilai-nilai karakter tertentu kepada peserta didik yang di dalamnya terdapat komponen pengetahuan, kesadaran atau kemauan, serta tindakan untuk melakukan nilai-nilai tersebut. ${ }^{12}$ Di dunia pendidikan akhir- akhir ini diramaikan oleh fenomena yang buruk, berbagai macam peristiwa yang muncul dan memberikan pengaruh pada kehidupan peserta didik yang menyimpang seperti

\footnotetext{
${ }^{7}$ E K A Lestari, "Upaya Guru Bimbingan Dan Konseling Dalam Membentuk Karakter Peserta Didik Di Madrasah Aliyah Negeri 2 Model Medan,” 2019.

${ }^{8}$ Muslihati Muslihati, "Peran Bimbingan Dan Konseling Dalam Penguatan Pendidikan Karakter Di Sekolah Menengah Kejuruan," Jurnal Kajian Bimbingan Dan Konseling 4, no. 3 (2019): 101, https://doi.org/10.17977/umoo1v4i32019p101.

${ }^{9}$ Muslihati.

${ }^{10}$ Asep Nanang Yuhana and Fadlilah Aisah Aminy, "Optimalisasi Peran Guru Pendidikan Agama Islam Sebagai Konselor Dalam Mengatasi Masalah Belajar Siswa," Jurnal Penelitian Pendidikan Islam 7, no. 1 (2019): 79, https://doi.org/10.36667/jppi.v7i1.357.

${ }^{11}$ Siti Zulaikah, "Penguatan Pendidikan Karakter Melalui Pendidikan Agama Islam Di Smpn 3 Bandar Lampung," Al-Tadzkiyyah: Jurnal Pendidikan Islam 10, no. I (2019): 83-93.

${ }^{12}$ A Syahdana and H E Romli, "Peranan Guru Bimbingan Dan Konseling Dalam Pembentukan Karakter Siswa Di Smp Negeri 36 Palembang,” ... Konseling, 2020, 1-9.
} 
menggunaan obat-obatan terlarang, tawuran,pelecehan seksual, bulliying dan lainlain, hal ini dikarenakan kurangnya pengetahuan dasar tentang pembentukan karakter, untuk itu penting sekali dangan adanya pendidikan karakter. ${ }^{13}$ Permasalah pembentukan karakter ini bukanlah hal yang baru bahkan sering sekali terjadi pada peserta didik, yang mana peserta didik tersebut kurang mampu mengoptimalkan prilaku yang menyimpang pada diri mereka, hal tersebut dipengaruhi oleh lingkungannya, maka dari itu siswa sangatlah penting mendapatkan pendidikan karakter. ${ }^{14}$

Tujuan dari penelitian ini ialah untuk dapat mengetahui bagaimana pentinya peran Guru BK dalam membentuk krakter peserta didik serta bagaimana upaya untuk menanganinya. Penelitian ini juga diharapkan bisa bermanfaat di masa depan dan bisa untuk menambah referensi literasi secara akademik mengenai Optimalisasi Peran Guru Bk Dalam Pembentukan Karakter Siswa, serta bisa membantu masyarakat maupun peserta didik dalam pembentukan karakter. Oleh karena itu penulis tertarik untuk melakukan suatu penelitian yang berjudul "Optimalisasi Peran Guru BK Dalam Pembentukan Karakter Siswa”.

\section{Metode Penelitian}

Penelitian ini menggunakan pendekatan kualitatif dengan jenis deskriptif yang bertujuan mendeskripsikan peran guru sebagai teladan dalam pengembangan karakter siswa. Pendekatan kualitatif dilakukan untuk mengkaji terhadap perilaku dan kejadian secara alami. Jenis deskriptif digunakan untuk menggambarkan kejadian yang nyata dalam sebuah hubungan fakta-fakta dengan menggunakan katakata rinci untuk merefleksikan data secara akurat dari perilaku manusia yang kompleks. Pendekatan kualitatif dengan jenis deskriptif dilakukan untuk mengumpulkan data secara mendalam mengenai kondisi nyata tentang peran guru sebagai teladan dalam pengembangan karakter siswa. Jenis penelitian deskriptif kualitatif merupakan sebuah metode penelitian yang memanfaatkan data kualitatif dan dijabarkan sejara deskriptif. ${ }^{15}$ Jenis penelitian deskriptif kualitatif kerap digunakan untuk menganalisis kejadian, fenomena, atau keadaan secara sosial.Jenis penelitian deskriptif kualitatif merupakan gabungan penelitian deskriptif dan kualitatif. Jenis penelitian deskriptif kualitatif menampilkan hasil data apa adanya tanpa proses manipulasi atau perlakuan lain. Metode ini juga menjelaskan seperangkat tahapan atau proses, serta untuk menyimpan informasi bersifat kontradiktif mengenai subjek penelitian. ${ }^{16}$

\footnotetext{
${ }^{13}$ Nur, "Peran Guru Bk Dalam Mengatasi Penyalahgunaan Media Sosial Pada Siswa Di Kecamatan Walenrang Utara Dan Lamasi."

${ }^{14}$ Wati, "Peran Guru BK Dalam Membentuk Karakter Siswa Melalui Layanan BK Kelompok."

${ }^{15}$ Robert T Sataloff, Michael M Johns, and Karen M Kost, "“Optimalisasi Active Learning Dan Character Building Dalam Meningkatkan Daya Saing Bangsa Di Era Masyarakat Ekonomi Asean (MEA)," n.d.

${ }^{16}$ Guallichico Mayra, "Strategi Komunikasi Guru BK Dalam Membentuk Karakter Positif Siswa SMA Negeri 4 Makassar," Journal of Chemical Information and Modeling 53, no. 9 (2013): 1689-99.
} 


\section{Hasil dan Pembahasan \\ Guru Bimbingan Konseling}

Soejipto dan Kosasi mengemukakan pengertian guru bimbingan dan konseling merupakan seseorang yang mempunyai tugas, tanggung jawab, wewenang, dan hak secara penuh dalam kegiatan bimbingan dan konseling terhadap sejumlah peserta didik. Bimbingan dan konseling mempunyai 17 layanan, tugas guru bimbingan dan konseling adalah menjalankan layanan tersebut jika dirangkum tujuan dari semua layanan tersebut ialah untuk memaksimakan hasil belajar perseta didik baik pembelajaran akademik maupun non-akademik. ${ }^{17}$ Guru bimbingan konseling bertugas sebagai pelayan perserta didik yang harus selalu siap dan sigap jika peserta didik membutuhkan termasuk membantu segala masalah dan apapun yang menghambat pemikiran dan ruang gerak mereka. Guru bimbingan konseling adalah salah satu dari tenaga kependidikan di sekolah, yaitu sebagai penanggung jawab terlaksananya kegiatan bimbingan dan konseling yang dilakukan oleh seseorang profesional yang memang terlatih dan memperoleh pendidikan secara akademik.

\section{Peran Bimbingan konseling dalam pembentukan karakter}

Sudrajat memuat artikel tentang pendidikan karakter dalam bimbingan dan konseling beliau menjelaskan bagaimana layanan bimbingan dan konseling dikaitkan pada pendidikan karakter. Berikut beberapa poin yang menjelaskan kaitan bimbingan dan konseling dengan pendidikan karakter :

a. Bimbingan dan konseling merupakan bagian integral dari sistem pendidikan nasional, maka orientasi, tujuan dan pelaksanaan BK juga merupakan bagian dari orientasi, tujuan dan pelaksanaan pendidikan karakter.

b. Program bimbingan dan konseling di sekolah merupakan bagian inti pendidikan karakter yang dilaksanakan dengan berbagai strategi pelayanan dalam upaya mengembangkan potensi peserta didik untuk mencapai kemandirian, dengan memiliki karakter yang dibutuhkan saat ini dan masa depan.

c. Pekerjaan bimbingan dan konseling adalah pekerjaan berbasis nilai, layanan etis normatif, dan bukan layanan bebas nilai. Seorang konselor perlu memahami betul hakekat Manusia dan perkembangannya sebagai makhluk sadar nilai dan perkembangannya ke arah normatif-etis. Seorang konselor harus memahami perkembangan nilai, namun seorang konselor tidak boleh memaksakan nilai yang dianutnya kepada konseli (peserta didik yang dilayani), dan tidak boleh meneladankan diri untuk ditiru konselinya, melainkan memfasilitasi konseli untuk menemukan makna nilai kehidupannya. ${ }^{18}$

\footnotetext{
${ }^{17}$ Mayra.

${ }^{18}$ Dian Novianti Sitompul, "Pengaruh Penerapan Layanan Bimbingan Kelompok Teknik Role-Playing Terhadap Perilaku Solidaritas Siswa Dalam Menolong Teman Di SMA Negeri 1 Rantau Utara T.A 2014/2015," Jurnal EduTech 1, no. 1 (2015): 1-12.
} 


\section{Pengertian Karakter}

Menurut bahasa, karakter adalah tabiat atau kebiasaan. Sedangkan menurut ahli psikologi, karakter adalah sebuah sistem keyakinan dan kebiasaan yang mengarahkan tindakan seorang individu. Karena itu, jika pengetahuan mengenai karakter seseorang itu dapat diketahui, maka dapat diketahui pula bagaimana individu tersebut akan bersikap untuk kondisi-kondisi tertentu. ${ }^{19}$ Individu yang berkarakter baik adalah individu yang bisa membuat keputusan dan siap mempertanggungjawabkan tiap akibat dari keputusan yang ia buat. Dilihat dari sudut pengertian, ternyata karakter dan akhlak tidak memiliki perbedaan yang signifikan. Keduanya didefinisikan sebagai suatu tindakan yang terjadi tanpa ada lagi pemikiran lagi karena sudah tertanam dalam pikiran, dan dengan kata lain, keduanya dapat disebut dengan kebiasaan.

Perspektif pendidikan sudah banyak yang secara utuh berbicara tentang tujuan pendidikan yaitu membentuk manusia berkarakter. Baik dari secara konsep agama maupun dalam diri kepribadian manusia. Seperti teori yang diungkapkan oleh Al Ghazali bahwa bentuk pendidikan yang ideal adalah memiliki 4 bentuk di dalamnya yaitu pendidikan akal, agama, akhlak dan jasmani. ${ }^{20}$ Dengan keempat bidang inilah manusia dapat mencapai tujuan hidup yaitu insan kamil.

\section{Proses Pembentukan Karakter Karakter}

Karakter yang kuat biasanya dibentuk dari penanaman nilai yang menekankan tentang baik dan buruk. Nilai ini dibentuk melalui penghayatan dan pengalaman, membangkitkan rasa ngin tahu dan bukan menyibukkan diri dengan pengetahuan. Anis Matta dalam Membentuk karakter Muslim menyebutkan beberapa kaidah pembentukan karakter, yaitu: Pertama, Kaidah kebertahapan Proses pembentukan dan pengembangan karakter harus dilakukan secara bertahap. Orientasi kegiatan ini adalah pada proses bukan pada hasil. Proses pendidikan adalah lama namun hasilnya paten. Kedua, Kaidah kesinambungan Proses yang berkesinambungan inilah yang nantinya membentuk rasa dan warna berfikir seseorang yang lama-lama akan menjadi kebiasaan dan seterusnya menjadi karakter pribadinya yang khas. Ketiga, Kaidah momentum Pergunakan berbagai momentum peristiwa untuk fungsi pendidikan dan latihan. Misalnya Ramadhan untuk mengembangkan sifat sabar, kemauan yang kuat, kedermawanan. Keempat Kaidah motivasi instrinsik Karakter yang kuat akan terbentuk sempurna jika dorongan yang menyertainya benar-benar lahir dari dalam diri sendiri. Jadi, proses merasakan sendiri, melakukan sendiri adalah penting. Hal ini sesuai dengan kaidah umum bahwa mencoba sesuatu akan berbeda hasilnya antara yang dilakukan sendiri dengan yang hanya dilihat atau diperdengarkan saja. Pendidikan harus menanamkan motivasi yang kuat dan lurus serta melibatkan aksi fisik yang nyata. Kelima, Kaidah pembimbingan Pembentukan karakter ini tidak bisa dilakukan tanpa seorang guru atau pembimbing. Kedudukan seorang guru/pembimbing ini adalah

\footnotetext{
19 Kabupaten Kuningan, "Peran Guru Ips Dalam Membentuk Karakter Sosial Siswadi Smpnegeri 1 Cigandamekar Kabupaten Kuningan,” 2015.

${ }^{20}$ Candra Ratnasari, "Membentuk Karakter Siswa (Studi Penerapan Bimbingan Dan Konseling Di MAN Yogyakarta II )," 2013.
} 
untuk memantau dan mengevaluasi perkembangan seseorang. Guru atau pembimbing juga berfungsi sebagai unsur perekat, tempat curhatdan sarana tukar pikiran bagi muridnya. ${ }^{21}$ Guru dengan peningkatan profesionalisme guru Pendidikan Agama Islam melalui self-efficacy dilakukan melalui; delegation of authority yang diberikan oleh pimpinan kepada guru, strengthening of self-commitment sebagai basis penguatan pengabdian, quality-oriented teacher behavior sebagai pembuatan budaya organisasi dan pembangunan sikap positive thinking untuk memperkuat kinerja dan jiwa pengabdian ${ }^{22}$.

Melalui pembiasaan mengikuti kegiatan keagamaan Islam bisa menumbuhkan karakter pada diri anak atau remaja muslim ${ }^{23}$, perlu pula melalukan kerjasama dengan orang tua dalam membentuk karakter anak, walaupun dibentuk sejak dini ${ }^{24}$, pendidikan karakter melalui pendidikan Agama. ${ }^{25}$

\section{Landasan BK dalam Membentuk Karakter}

Pada dasarnya BK merupakan bagian dari instrumen dari pendidikan karakter. Hal ini bisa dilihat dari sebuah sistem keyakinan dan kebiasaan yang mengarahkan tindakan seorang individu. Karena itu, jika pengetahuan mengenai karakter seseorang itu dapat diketahui, maka dapat diketahui pula bagaimana individu tersebut akan bersikap untuk kondisi-kondisi tertentu. ${ }^{26}$ Individu yang berkarakter baik adalah individu yang bisa membuat keputusan dan siap mempertanggungjawabkan tiap akibat dari keputusan yang di buat. Membentuk karakter tidak bisa dilakukan dalam sekejap dengan memberikan nasihat, perintah, atau instruksi, namun lebih dari hal tersebut. Pembentukan karakter memerlukan teladan atau role model, kesabaran, pembiasaan,dan pengulangan. ${ }^{27}$ Dengan demikian proses pendidikan karakter merupakan proses pendidikan yang dialami oleh siswa sebagai bentuk pengalaman pembentukan kepribadian melalui mengalami sendiri nilai-nilai kehidupan, agama, dan moral.

Dalam kegiatan proses pembelajaran, membentuk siswa berkarakter dapat dimulai dari pembuatan perencanaan pelaksanaan pembelajaran (RPP). Karakter

\footnotetext{
${ }^{21}$ Ratnasari.

22 Hasan Baharun et al., "Self-Efficacy Sebagai Media Peningkatan Profesionalisme Guru Di Madrasah,” Risâlah, Jurnal Pendidikan Dan Studi Islam 6, no. 2 (2020): 344-57, https://doi.org/10.31943/jurnal_risalah.v6i2.158.

${ }^{23}$ Ade Aspandi, "Pengelolaan Pendidikan Karakter Terhadap Remaja Melalui Pendekatan Nilai-Nilai Keislaman," Risâlah, Jurnal Pendidikan Dan Studi Islam 6, no. 2 (2020): 243-56, https://doi.org/10.31943/jurnal_risalah.v6i2.151.

${ }^{24}$ Aisyah et al., "Persepsi Orang Tua Dalam Pendidikan Karakter Anak Usia Dini Pada Pembelajaran Online Di Masa Pandemi Covid-19,” PEDAGOGI: Jurnal Anak Usia Dini Dan Pendidikan Anak Usia Dini 7, no. 1 (2021): 6o-75.

${ }^{25}$ Nur Ainiyah, "Pembentukan Karakter Melalui Pendidikan Islam,” Jurnal Al-Ulum 13, no. 1 (2013): 2538, https://doi.org/10.34005/tahdzib.v2i2.511.

${ }^{26}$ Febrina Sanderi, Marjohan, and Indah Sukmawati, "Kepatuhan Siswa Terhadap Disiplin Dan Upaya Guru Bk Dalam Meningkatkannya Melalui Layanan Informasi,” Konselor 2, no. 1 (2013): 220-24, https://doi.org/10.24036/o2013211008-0-oo.

${ }^{27}$ Indun Ariningsih and Rizki Amalia, "Membangun Karakter Siswa Melalui Pembelajaran Matematika Yangg Berintegrasi Keislaman," Journal on Teacher Education 1 (2020): 1-8.
} 
yang akan dikembangkan dapat ditulis secara eksplisit pada RPP. ${ }^{28}$ Dengan demikian, dalam setiap kegiatan pembelajaran BK perlu menetapkan karakter yang akan dikembangkan sesuai dengan materi, metode, dan strategi pembelajaran. Ketika guru ingin menguatkan karakter kerjasama, disiplin waktu, keberanian, dan percaya diri, maka guru perlu memberikan kegiatan-kegiatan dalam proses pembelajaran sehari- hari. Seperti kita ketahui bahwa belajar tidak hanya untuk mendapatkan ilmu pengetahuan saja, namun juga dapaT menerapkan ilmu pengetahuan dalam bentukkarya yang mencerminkan keterampilan dan meningkatkan sikap positif. ${ }^{29}$ Secara singkat, menurut beberapa literatur Triatna dan Permana menyatakan bahwah masalah pembentukan karakter pada siswa ini ialah Pembentukan karakter Anak merupakan salah satu wujud kepedulian terhadap kesejahteraan anak di masa depan.

Semua komponen bangsa, mulai dari orang tua, keluarga, masyarakat, dunia usaha, pemerintah, dan negara, memiliki kewajiban dan tanggung jawab terhadap perlindungan dan kesejahteraan anak Unsur terpenting dalam pembentukan karakter adalah pikiran. Hal ini karena didalam pikiran terdapat seluruh program yang terbentuk dari pengalaman hidupnya. Permasalahan yang dialami para peserta didik disekolah sering kali tidak terhindar dengan pengajaran yang baik sekalipun. ${ }^{30}$ Hal ini terlebih lagi disebabkan karena sumber-sumber permasalahan peserta didik banyak yang terletak di luar sekolah yaitu seperti lingkungan tempat tinggalnya. Disini peran Guru BK sangatlah penting guna membantu peserta didik menemukan dan memahami jati dirinya serta mengembangkan pribadi yang lebih baik dari sebelumnya. Layanan bimbingan dan konseling yang diberikan di sekolah dasar mencakup komponen bimbingan pribadi, sosial, belajar karier dan kelompok. ${ }^{31}$

\section{Pengertian Bimbingan Kelompok}

Adapun cara pembentukan karakter pada siswa dengan melakukan bimbingan kelompok, Menurut para ahli Amin bimbingan kelompok ialah merupakan bimbingan pemberian pertolongan atau bantuan, dan bantuan itu merupakan hal yang pokok dalam bimbingan. Menurut Juntika, bimbingan kelompok dimaksudkan untuk mencegah berkembangnya masalah atau kesulitan pada diri konseli (siswa). Dapat disimpulakan Layanan bimbingan kelompok merupakan suatu cara memberikan bantuan (bimbingan) kepada individu (siswa) melalui kegiatan kelompok. ${ }^{32}$

Dalam layanan bimbingan kelompok, aktivitas dan dinamika kelompok harus diwujudkan untuk membahas berbagai hal yang berguna bagi pengembangan

\footnotetext{
${ }^{28}$ Kuningan, "Peran Guru Ips Dalam Membentuk Karakter Sosial Siswadi Smpnegeri 1 Cigandamekar Kabupaten Kuningan."

29 Moh Khoerul Anwar, "Pembelajaran Mendalam Untuk Membentuk Karakter Siswa Sebagai Pembelajar," Tadris: Jurnal Keguruan Dan Ilmu Tarbiyah 2, no. 2 (2017): 97, https://doi.org/10.24042/tadris.v2i2.1559.

${ }^{30}$ Anwar.

${ }^{31}$ Abdur Rahman Lubis, Skripsi Prodi Bimbingan Konseling Islam Universitas Islam Negerisumatera Utara, 2019.

32 Sitompul, "Pengaruh Penerapan Layanan Bimbingan Kelompok Teknik Role-Playing Terhadap Perilaku Solidaritas Siswa Dalam Menolong Teman Di SMA Negeri 1 Rantau Utara T.A 2014/2015.”
} 
atau pemecahan bagi masalah individu (siswa) yang menjadi peserta layanan. Kesimpulan dari pendapat diatas bimbingan kelompok merupakan suatu cara pemberian bantuan yang diberikan kepada individu untuk mencegah berkembangnya masalah yang ada pada diri konseli (siswa) yang membahas berbagai informasi dan hal-hal yang berguna untuk memperbaiki dan pemahaman diri dan mendapat pemecahan dari masalah individu. ${ }^{33}$ Arti lain dari Bimbingan Kelompok merupakan salah satu teknik bimbingan konseling yang efektik untuk pembentukan karakter siswa dengan berusaha membantu individu mencapai perkembangannya secara optimal sesuai dengan kemampuan, bakat, minat, serta nilai-nilai yang dianutnya. ${ }^{34}$ Adapun bentuk kegiatan kelompok yang lebih intensif yang bersifat perbaikan dan penyembuhan yang menekankan pada perubahan perilaku dan kepribadian dikenal dengan nama konseling kelompok dan psikoterapi kelompok.

Hal ini merupakan Guru BKuntuk membantu peserta didik agar dapat menjalani perkembangan dengan lancar. ${ }^{35}$ Kriteria pencapaian pendidikan karakter adalah terbentuknya budaya sekolah, yaitu perilaku, tradisi, kebiasaan keseharian, dan simbol -simbol yang dipraktikkan oleh semua warga sekolah, dan masyarakat sekitar sekolah harus berlandaskan nilai -nilai tersebut. Penbentukan karakter siswa bukan hanya penting bagi peserta didik saja tetapi juga memiliki pengaruh yang besar dalam masyarakat luas, karena jika pembentukan karakter tidak di terapkan sejak dini akan berpengaruh di kemudian hari, yang mana akan menimbulkan masalah-masalah yang tidak di inginkan pada peserta didik dan sangat berpengaruh dengan karier peserta didik, oleh sebab itulah kenapa pendidikan karakter sejak dini itu penting. ${ }^{36}$ Dari hal tersebut, maka layanan yang diberikan oleh konselor sekolah dapat bersifat preventif, kuratif, dan preseveratif atau developmental ${ }^{37}$ dalam rangka menunaikan fungsi pendidikan dalam mengembangkan karakter siswa. Layanan yang bersifat preventif berarti kegiatan yang dilakukan oleh konselor sekolah bermaksud untuk mencegah agar perilaku siswa tidak berlawanan dengan karakter yang diharapkan. Layanan yang bersifat kuratif bermakna bahwa layanan konselor ditujukan untuk mengobati atau memperbaiki perilaku siswa yang sudah terlanjur melanggar karakter yang diharapkan. ${ }^{38}$

\footnotetext{
33 Sitompul.

${ }^{34}$ Nur, "Peran Guru Bk Dalam Mengatasi Penyalahgunaan Media Sosial Pada Siswa Di Kecamatan Walenrang Utara Dan Lamasi."

35 Sataloff, Johns, and Kost, ““'Optimalisasi Active Learning Dan Character Building Dalam Meningkatkan Daya Saing Bangsa Di Era Masyarakat Ekonomi Asean (MEA).”

36 "Peran Konselor Dalam Pendidikan Nasional Sebagai Model Dalam Pembentukan Karakter Siswa Di Sekolah," n.d.

37 Wati, "Peran Guru BK Dalam Membentuk Karakter Siswa Melalui Layanan BK Kelompok."

${ }^{38}$ Hendriyani, "Optimalisasi Peran Guru Bimbingan Dan Konseling Dalam Mereduksi Nomphobia."
} 


\section{Simpulan}

Dari pemaparan di atas, maka dapat disimpulkan upaya Guru BK dalam pembentukan karakter siswa sangatlah penting, karena pendidikan karakter pada umumnya sangat dibutuhkan bagi individu dari sejak dini yang mana pendidikan karakter ialah suatu sistem pendidikan yang bertujuan untuk menanamkan nilainilai karakter tertentu kepada peserta didik yang di dalamnya terdapat komponen pengetahuan, kesadaran atau kemauan, serta tindakan untuk melakukan nilai-nilai tersebut. Salah satu cara untuk pembentukan karakter pada siswa ialah dengan menggunakan motode bimbingan kelompok, Bimbingan Kelompok merupakan salah satu teknik bimbingan konseling yang efektik untuk pembentukan karakter siswa dengan berusaha membantu individu mencapai perkembangannya secara optimal sesuai dengan kemampuan, bakat, minat, serta nilai-nilai yang dianutnya. Saran disampaikan untuk penelitian dimasa akan datang untuk mendeskripsikan stres bagi siswa yang memasuki masa orientasi siswa baru, terutama bagi sekolah yang menggunakan aktivitas pola militer untuk menegakkan disiplin siswa, sehingga dapat melihat dan mengetahui bagaimana manajemen stres bagi siswa tersebut.

\section{DAFTAR PUSTAKA}

Ainiyah, Nur. "Pembentukan Karakter Melalui Pendidikan Islam.” Jurnal Al-Ulum 13, no. 1 (2013): 25-38. https://doi.org/10.34005/tahdzib.v2i2.511.

Aisyah, Mohammad Salehudin, Sri Yatun, Yani, Denok Lailatin Komariah, Nur Eka Rizky Aminda, Pratiwi Hidayati, and Nur Latifah. "Persepsi Orang Tua Dalam Pendidikan Karakter Anak Usia Dini Pada Pembelajaran Online Di Masa Pandemi Covid-19." PEDAGOGI: Jurnal Anak Usia Dini Dan Pendidikan Anak Usia Dini 7, no. 1 (2021): 6o-75.

Anwar, Moh Khoerul. "Pembelajaran Mendalam Untuk Membentuk Karakter Siswa Sebagai Pembelajar.” Tadris: Jurnal Keguruan Dan Ilmu Tarbiyah 2, no. 2 (2017): 97. https://doi.org/10.24042/tadris.v2i2.1559.

Ariningsih, Indun, and Rizki Amalia. "Membangun Karakter Siswa Melalui Pembelajaran Matematika Yangg Berintegrasi Keislaman.” Journal on Teacher Education 1 (2020): 1-8.

Aspandi, Ade. "Pengelolaan Pendidikan Karakter Terhadap Remaja Melalui Pendekatan Nilai-Nilai Keislaman.” Risâlah, Jurnal Pendidikan Dan Studi Islam 6, no. 2 (2020): 243-56. https://doi.org/10.31943/jurnal_risalah.v6i2.151.

Astuti, Anita Dewi. "Optimalisasi Peran Guru Bimbingan Dan Konseling Dalam Menguatkan Nilai-Nilai Moral Remaja Yang Berkarakter.” Prosiding Nasional, 2017, 27-36.

Baharun, Hasan, Muhammad Mushfi El Iq Bali, Chusnul Muali, and Laili Munawaroh. "Self-Efficacy Sebagai Media Peningkatan Profesionalisme Guru Di Madrasah.” Risâlah, Jurnal Pendidikan Dan Studi Islam 6, no. 2 (2020): 344-57. https://doi.org/10.31943/jurnal_risalah.v6i2.158.

Hardi Prasetiawan. "Peran Bimbingan Dan Konseling Dalam Pendidikan Ramah Anak Terhadap Pembentukan Karakter Sejak Usia Dini." Jurnal CARE (Children Advisory Research and Education) o4 (2016): 42-49. 
Hendriyani, Tuti. "Optimalisasi Peran Guru Bimbingan Dan Konseling Dalam Mereduksi Nomphobia.” Prosiding Seminar Nasional E Call Paper Psikologi Pendidikan 2019, 2019, 123-26.

Kuningan, Kabupaten. "Peran Guru Ips Dalam Membentuk Karakter Sosial Siswadi Smpnegeri 1 Cigandamekar Kabupaten Kuningan,” 2015.

Lestari, E K A. "Upaya Guru Bimbingan Dan Konseling Dalam Membentuk Karakter Peserta Didik Di Madrasah Aliyah Negeri 2 Model Medan," 2019.

Lubis, Abdur Rahman. Skripsi Prodi Bimbingan Konseling Islam Universitas Islam Negerisumatera Utara, 2019.

Mayra, Guallichico. "Strategi Komunikasi Guru BK Dalam Membentuk Karakter Positif Siswa SMA Negeri 4 Makassar." Journal of Chemical Information and Modeling 53, no. 9 (2013): 1689-99.

Muslihati, Muslihati. "Peran Bimbingan Dan Konseling Dalam Penguatan Pendidikan Karakter Di Sekolah Menengah Kejuruan.” Jurnal Kajian Bimbingan Dan Konseling 4, no. 3 (2019): 101. https://doi.org/10.17977/umoo1v4i32019p101.

Nur, Alam. "Peran Guru Bk Dalam Mengatasi Penyalahgunaan Media Sosial Pada Siswa Di Kecamatan Walenrang Utara Dan Lamasi.” Jurnal Panrita 1, no. 1 (2020):31-40. https://doi.org/10.35906/panrita.vii1.130.

"Peran Konselor Dalam Pendidikan Nasional Sebagai Model Dalam Pembentukan Karakter Siswa Di Sekolah,” n.d.

Pertama, Menengah, Negeri Depok, and Rina Palunga. "Peran Guru Dalam Pengembangan Karakter Peserta Didik Di Sekolah Menengah Pertama Negeri 2 Depok Sleman." Jurnal Pendidikan Karakter 7, no. 1 (2017): 109-23. https://doi.org/10.21831/jpk.v7i1.20858.

Ratnasari, Candra. "Membentuk Karakter Siswa (Studi Penerapan Bimbingan Dan Konseling Di MAN Yogyakarta II )," 2013.

Sanderi, Febrina, Marjohan, and Indah Sukmawati. "Kepatuhan Siswa Terhadap Disiplin Dan Upaya Guru Bk Dalam Meningkatkannya Melalui Layanan Informasi." Konselor 2, no. 1 (2013): 220-24. https://doi.org/10.24036/02013211008-0-0o.

Sataloff, Robert T, Michael M Johns, and Karen M Kost. “' Optimalisasi Active Learning Dan Character Building Dalam Meningkatkan Daya Saing Bangsa Di Era Masyarakat Ekonomi Asean (MEA)," n.d.

Sitompul, Dian Novianti. "Pengaruh Penerapan Layanan Bimbingan Kelompok Teknik Role-Playing Terhadap Perilaku Solidaritas Siswa Dalam Menolong Teman Di SMA Negeri 1 Rantau Utara T.A 2014/2015." Jurnal EduTech 1, no. 1 (2015): 1-12.

Syahdana, A, and H E Romli. "Peranan Guru Bimbingan Dan Konseling Dalam Pembentukan Karakter Siswa Di Smp Negeri 36 Palembang.” ... Konseling, 2020, 1-9.

Wati, Misra. "Peran Guru BK Dalam Membentuk Karakter Siswa Melalui Layanan BK Kelompok.” PEMBELAJAR: Jurnal Ilmu Pendidikan, Keguruan, Dan Pembelajaran 1, no. 2 (2017): 65. https://doi.org/10.26858/pembelajar.vii2.3482. 
Ayu Santika S. \& Mohammad Salehudin

Optimalisasi Peran Guru Bimbingan......

Yuhana, Asep Nanang, and Fadlilah Aisah Aminy. "Optimalisasi Peran Guru Pendidikan Agama Islam Sebagai Konselor Dalam Mengatasi Masalah Belajar Siswa." Jurnal Penelitian Pendidikan Islam 7, no. 1 (2019): 79. https://doi.org/10.36667/jppi.v7i1.357.

Zulaikah, Siti. "Penguatan Pendidikan Karakter Melalui Pendidikan Agama Islam Di Smpn 3 Bandar Lampung." Al-Tadzkiyyah: Jurnal Pendidikan Islam 10, no. I (2019): 83-93. 